\title{
PELATIHAN PENELITIAN TINDAKAN KELAS DENGAN VARIASI METODE DAN MEDIA PEMBELAJARAN UNTUK MENINGKATKAN KEMAMPUAN PENULISAN KARYA ILMIAH GURU-GURU SMK NEGERI 3 YOGYAKARTA
}

\author{
Herminarto Sofyan, Wardan Suyanto, Agus Budiman, Ibnu Siswanto*, Agung Gumelar, \\ Wahyu Arya Ruswanto \\ Pendidikan Teknik Otomotif, Universitas Negeri Yogyakarta \\ *Email: ibnusiswanto@uny.ac.id
}

\begin{abstract}
The Community Service Program (PPM) at SMKN 3 Yogyakarta aims to (1) increase the motivation of teachers to conduct action research and write papers, (2) increase teachers' ability to select and use appropriate learning methods and media to conduct classroom action research, (3) increase the competence of vocational school teachers in writing scientific papers, (4) increase teachers' knowledge in accessing scientific journals and conference to publish their work. The activity was attended by 25 participants consisting of 16 productive subject teachers and 9 normative/adaptive subject teachers. The activities carried out in the form of presentation of material about the importance of increasing teacher productivity in publishing scientific work to enhance careers, design action research in the classroom by implementing appropriate media variations and learning methods, writing strategies and publishing articles in journals and proceedings, tutorial guidance on writing articles, and the practice of compiling scientific articles. This PPM activity succeeded in increasing the motivation of teachers to conduct research and write scientific papers, improve the ability of teachers to select the right learning media and methods for conducting classroom action research, increase participants' ability to write articles, increase teachers' knowledge in accessing scientific journals and conference to publish their work. Participants satisfy to get new knowledge and skills about classroom action research techniques, they are open-minded and wish to further enhance their ability to conduct classroom action research and write articles to be published in proceedings/journals.
\end{abstract}

Keywords: training, classroom action research, articles, vocational teachers

\begin{abstract}
Abstrak
Program Pengabdian pada Masyarakat (PPM) di SMKN 3 Yogyakarta ini bertujuan untuk (1) meningkatkan motivasi tenaga pendidik/guru untuk melakukan penelitian dan menulis karya ilmiah, (2) meningkatkan kemampuan guru dalam memilih serta menggunakan metode dan media pembelajaran yang tepat untuk melakukan kegiatan penelitian tindakan kelas, (3) meningkatkan kompetensi tenaga pengajar SMK dalam menulis karya ilmiah, (4) meningkatkan pengetahuan guru dalam mengakses jurnal dan forum ilmiah untuk mempublikasikan karya mereka. Kegiatan diikuti oleh 25 peserta yang terdiri dari 16 guru mata pelajaran produktif dan 9 guru mata pelajaran normatif/adaptif. Kegiatan yang dilakukan berupa pemaparan materi tentang pentingnya meningkatkan produktifitas guru dalam menghasilkan karya ilmiah untuk meningkatkan karir, merancangan action research di kelas dengan mengimpelementasikan variasi media dan metode pembelajaran yang tepat, strategi penulisan dan publikasi artikel dalam jurnal dan prosiding, bimbingan tutorial tentang penulisan artikel, dan praktik penyusunan artikel ilmiah. Kegiatan PPM ini berhasil meningkatkan motivasi guru untuk melakukan penelitian dan menulis karya ilmiah, meningkatkan kemampuan guru dalam memilih media dan metode pembelajaran yang tepat untuk melakukan kegiatan PTK, meningkatkan kemampuan peserta dalam
\end{abstract}


menyusun artikel ilmiah, meningkatkan pengetahuan guru dalam mengakses jurnal dan forum ilmiah untuk mempublikasikan karya mereka. Peserta merasa senang mendapatkan pengetahuan dan keterampilan baru tentang teknik penelitian tindakan kelas, mereka terbuka wawasannya dan berkeinginan untuk lebih meningkatkan kemampuannya dalam melakukan PTK dan menyusun artikel ilmiah untuk dipublikasikan ke prosiding/jurnal.

Kata kunci: pelatihan, PTK, karya ilmiah, guru kejuruan

\section{PENDAHULUAN}

Pengembangan profesi guru dilakukan secara berkelanjutan dan terus-menerus supaya dapat meningkatkan kualitas mutu pendidikan yang meliputi proses belajar mengajar, komptetensi tenaga kependidikan, dan mutu lulusan. Bentuk upaya peningkatan kompetensi guru dapat dilakukan melalui program 1) pengembangan karya tulis/karya ilmiah, 2) pengembangan teknologi sesuai bidang profesional guru, 3) pengembangan alat peraga pembelajaran, dan 4) pengembangan kurikulum (Depdiknas, 2001). Selain bermanfaat secara langsung dalam peningkatan mutu pendidikan, kegiatan-kegiatan tersebut juga menjadi syarat bagi guru-guru yang akan mengembangkan karir untuk mencapai pangkat dan golongan tertentu.

Sebagai salah satu pemeran utama dalam pencapaian tujuan pendidikan, tenaga pendidik memiliki kontribusi secara langsung dan tidak langsung terhadap pembangunan bangsa dan negara (Barber \& Mourshed, 2007). Oleh sebab itu, pemerintah harus memberikan perhatian yang lebih terhadap kualitas tenaga pendidik ketika ingin mendapatkan luaran hasil pendidikan yang berkualitas (Stronge, 2013). Bentuk perhatian dari pemerintah salah satunya diwujudkan dalam kebijakan anggaran dengan memberikan imbalan yang layak bagi guru dan tenaga kependidikan lainnya. Peraturan pemerintah tentang guru menyebutkan bahwa sebagai tenaga fungsional, guru dapat naik pangkat kurang dari 4 tahun selama memenuhi persyaratan dan ketentuan angka kredit. Dengan adanya peraturan ini, tenaga pendidik di sekolah dapat mencapai pangkat lebih tinggi dibandingkan birokrat yang berkarir di jalur struktural.

Akan tetapi, dalam realitasnya banyak guru yang mengalami permasalahan dalam peningkatan karir dan jabatannya. Pada periode sebelum tahun 2009, banyak guru yang karirnya berhenti di jenjang Iva/Pembina saja karena ada ketentuan persyaratan pembuatan karya ilmiah untuk kenaikan pangkat tersebut. Selanjutnya, berdasarkan Keputusan Menteri No. 14 tahun 2009, bagi guru yang akan naik pangkat dari IIIb ke IIIc juga diwajibkan mempublikasikan karya ilmiah atau artikel sebagai salah satu syarat untuk kenaikan pangkat. 
Hal ini menyebabkan guru-guru yang mulai meniti karirnya, sejak awal sudah harus memiliki kemampuan untuk membuat karya ilmiah.

SMK Negeri 3 Yogyakarta atau STM 2 Jetis merupakan salah satu SMK negeri di Yogyakarta yang telah berdiri sejak tahun 1965 dan berlokasi di JL. RM. Monginsidi No. 02 Cokrodiningratan Yogyakarta.. Jumlah guru di SMKN 3 Yogyakarta sebanyak 136 guru yang menjadi tenaga pendidik bagi 1,529 siswa laki-laki dan 201 siswa perempuan. Sebanyak 97,06\% guru sudah memenuhi kualifikasi pendidikan S1, dan 87,5\% sudah mendapatkan pengakuan sertifikat sebagai tenaga pendidik professional. Selain itu, 86,76\% dari total guru merupakan guru PNS sehingga untuk pengembangan karirnya memerlukan penulisan dan publikasi karya ilmiah.

Berdasarkan penelitian yang dilaksanakan Herminarto Sofyan dan Zainal Arifin (2016) mengenai implementasi pembelajaran saintifik pada SMK program keahlian Teknik Otomotif ditemukan fakta bahwa guru-guru SMK Otomotif sudah mampu membuat perencanaan pelaksanaan pembelajaran saintifik dengan menggunakan materi, metode, dan media yang baik. Akan tetapi dalam proses pelaksanaannya masih terdapat kekurangan yaitu tentang 1) penentuan model pembelajaran, 2) penentuan media dan alat pembelajaran, dan 3) pengelolaan kelas oleh guru yang membangkitkan motivasi siswa. Oleh karena itu disarankan untuk memberikan pelatihan bagi guru-guru SMK tentang berbagai variasi metode dan media pembelajaran yang dapat dilakukan untuk mengimplementasikan pembelajaran saintifik dalam proses pembelajaran di kelas. Ketika program pelatihan tentang implementasi metode dan media pembelajaran ini ditawarkan ke SMKN 3 Yogyakarta, pihak sekolah mengharapkan kegiatan ini diintegrasikan untuk mengatasi permasalahan lain yang terkait yaitu tentang penulisan artikel ilmiah bagi tenaga pengajar di SMKN 3 Yogyakarta.

Dengan latar belakang sebagaimana dibahas di atas, maka kegiatan ini bertujuan untuk 1) Meningkatkan motivasi guru untuk melakukan penelitian dan menulis artikel/karya ilmiah, 2) Meningkatkan kemampuan guru dalam memilih median dan metode pembelajaran yang sesuai untuk pelaksanaan PTK, 3) Meningkatkan kemampuan dan ketrampilan tenaga pendidik/guru dalam menulis artikel/karya ilmiah, dan 4) Meningkatkan pengetahuan guru dalam mengakses jurnal dan forum ilmiah untuk mempublikasikan karya mereka.

\section{METODE}

Sasaran kegiatan ini adalah para guru SMK Negeri 3 Yogyakarta dengan mempertimbangkan permasalahan yang telah diidentifikasi dan juga sebagai upaya 
peningkatan kualitas pendidikan di Indonesia melalui upaya pengembangan karir tenaga pendidikan khususnya di SMKN 3 Yogyakarta. Kegiatan dilaksanakan pda bulan Mei-Agustus 2019. Metode kegiatan yang dilakukan berupa pelatihan dan tutorial terbimbing untuk melaksanakan hasil pelatihan dalam rangka meningkatkan profesionalitas dan karir mereka. Berikut ini adalah tahapan pelatihan bagi guru SMKN 3 Yogyakarta yang dilakukan.

a. Tahap Persiapan

Tahap persiapan pelatihan yang dilakukan diawali dengan survey lokasi kegiatan dan penyusunan bahan serta materi pelatihan.

b. Tahap Pelaksanaan Pelatihan

Tahap pelaksanaan terdiri dari pemberian motivasi pengembangan karir bagi guru, pemberian bekal pengetahuan sekaligus kemampuan melakukan penelitian tindakan kelas serta menulis karya ilmiah berupa artikel ataupaun laporan hasil penelitian. Sedangkan tahap terakhir yaitu bagaimana guru-guru dapat mempublikasikan karyanya dalam seminar ataupun jurnal.

c. Rancangan Evaluasi

Evaluasi pelaksanaan kegiatan dilaksanakan selama persiapan, proses, dan akhir pelaksanaan pelatihan baik pada saat proses penyajian materi maupun pada saat praktek/latihan. Evaluasi pada saat proses pelatihan dilaksanakan menggunakan metode dengan tanya jawab. Sedangkan evaluasi pada akhir dan setelah pelatihan dilakukan dengan studi dokumen terhadap karya tulis yang dihasilkan.

\section{HASIL PELAKSANAAN KEGIATAN}

\section{Persiapan kegiatan pelatihan (pra-workshop)}

Kegiatan PPM ini diikuti oleh 25 peserta dari SMKN 3 Yogyakarta yang terdiri dari 16 guru mata pelajaran produktif dan 9 guru mata pelajaran normatif/adaptif. Peserta mempunyai golongan dan masa kerja yang berbeda-beda. Rincian peserta berdasarkan masa kerja yaitu 5-10 tahun ada 2 peserta, 10-15 tahun ada 9 peserta, dan $>15$ tahun ada 14 peserta. Sedangkan rincian peserta berdasarkan golongannya yaitu IIIA ada 4 peserta, IIIB ada 2 peserta, IIIC 8 peserta, IIID 4 peserta, IVA 4 peserta, dan IVB sebanyak 3 peserta. Dari hasil penelitian diperoleh (1) terdapat 11 peserta mempunyai kegiatan penelitian yang sudah selesai dilakukan, akan tetapi belum dibuat artikel jurnalnya, (2) terdapat 23 guru yang berminat untuk melakukan kegiatan penelitian tindakan kelas tahun ini, (3) Pada penawaran beberapa materi yang dibutuhkan bagi peserta, terdapat 19 peserta yang membutuhkan materi pelatihan 
tentang pelaksanaan PTK, 10 peserta membutuhkan materi tentang menulis laporan PTK, 11 peserta membutuhkan materi tentang pembuatan artikel jurnal, dan terdapat 1 peserta yang membutuhkan pelatihan membuat proposal R\&D.

\section{Pelaksanaan pelatihan (workshop)}

Kegiatan pemberian materi dimulai pada hari Jum'at, 24 Mei 2019 di ruang sidang FT UNY. Materi yang diberikan pada pelatihan hari pertama yaitu (1) urgensi menulis dan mempublikasikan karya tulis ilmiah untuk meningkatkan karir guru/tenaga pendidik, (2) Penelitian tindakan kelas (PTK) dengan menggunakan berbagai variasi media dan metode pembelajaran yang sesuai, (3) Strategi penulisan dan publikasi karya ilmiah dalam prosiding dan jurnal. Kegiatan diawali pada pukul 08.00 WIB dengan pembukaan oleh Kepala Sekolah SMKN 3 Yogyakarta dan sambutan dari tim pelaksana PPM. Kemudian dilanjutkan pemberian materi yang pertama yaitu "Urgensi penulisan karya tulis ilmiah untuk meningkatkan karir serta pengetahuan guru SMKN 3 Yogyakarta" yang disampaikan selama kurang lebih 1 jam menggunakan projector sehingga peserta dapat lebih mudah menangkap dan memahami materi yang disampaikan. Pada materi pertama ini peserta diberikan pengetahuan mengenai tantangan kedepan bagi sekolah dan guru, permasalahan-permasalahan yang sering terjadi disekolah, dan pentingnya penelitian tindakan kelas untuk menyelesaikan permasalahan-permasalahan tersebut.

Pemaparan materi pertama diakhiri pada pukul 09.30 kemudian dilanjutkan pemberian materi yang kedua yaitu "Penelitian tindakan kelas dengan variasi media dan metode pembelajaran". Pemaparan materi dijeda pada pukul 11.30 untuk istirahat sholat jum'at".

Kegiatan dimulai kembali pada pukul 13.15 untuk melanjutkan pemaparan materi yang kedua. Dengan dilakukannya pemberian materi yang kedua ini, peserta mendapat pengarahan mengenai sejarah penelitian tindakan kelas, maksud dari penelitian tindakan kelas, prinsip-prinsip dasar dan karakteristik PTK, tujuan dan manfaat, dan langkah-langkah dari penelitian tindakan kelas beserta cara melakukannya. Selain itu juga dipaparkan perbedaan penelitian tindakan kelas dengan penelitian lain serta kelebihan dan kekurangan penelitian tindakan kelas. Dengan demikian diharapkan peserta dapat lebih memahami mengenai penelitian tindakan kelas dan prosedur pelaksanaannya.

Pemberian materi kedua diakhiri pada pukul 14.30, kemudian dilanjutkan materi yang ketiga yaitu "strategi penulisan dan publikasi artikel/karya ilmiah dalam prosiding dan 
jurnal". Pada materi yang ketiga ini peserta diberikan paparan mengenai pentingnya karya tulis ilmiah, pengertian dan macam-macam artikel/karya tulis ilmiah, pemilihan materi karya ilmiah, dan strategi dalam menulis karya ilmiah.

Kegiatan dihari kedua dilaksanakan pada hari Sabtu tanggal 25 Mei 2019. Materi yang disampaikan kepada peserta pelatihan pada hari kedua yaitu mengenai sistematika artikel ilmiah dalam prosiding dan jurnal, serta dilanjutkan dengan tutorial penulisan artikel/karya ilmiah dan praktik penyusunan karya tulis ilmiah. Pemberian materi dimulai pada pukul 08.30. Pada kegiatan ini peserta mendapat pengetahuan mengenai sistematika dalam penulisan artikel prosiding dan jurnal dan berakhir pada pukul 10.00. Kegiatan kemudian dilanjutkan dengan pemberian tutorial penulisan karya ilmiah/artikel baik artikel prosiding ataupun jurnal. Berdasarkan hasil penelitian/survey diketahui ada 11 peserta yang sudah mempunyai kegiatan penelitian namun belum dibuat artikel jurnalnya, oleh karenanya pada tahap kegiatan ini para peserta pelatihan dibagi menjadi 2 kelompok yaitu kelompok pertama dengan materi tutorial pembuatan artikel jurnal bagi peserta yang sudah selesai melakukan kegiatan penelitian namun belum dibuat artikel jurnalnya, dan kelompok kedua dengan materi pembuatan proposal penelitian bagi peserta yang belum mempunyai kegiatan penelitian.

Pada kegiatan ini, peserta tidak hanya diberikan tutorial mengenai teknik penulisan saja, namun juga diberikan pendampingan untuk submit sehingga dapat mempublikasikan artikel mereka ke jurnal online/prosiding yang sesuai sehingga peserta memiliki pengalaman langsung yang dapat dijadikan sebagai panduan bagi peserta untuk mempublikasikan karya ilmiah mereka di masa yang akan datang. Kegiatan diakhiri untuk istirahat sholat dan makan siang pada pukul 11.30.

Pada pukul 13.00 dilanjutkan kegiatan yang terakhir yaitu praktik penulisan karya tulis ilmiah. Pada kegiatan ini, setiap peserta dipersilahkan untuk praktik menulis karya tulis ilmiah menggunakan perangkat laptop masing-masing. Bagi peserta yang sudah memiliki kegiatan penelitian dilakukan praktik pembuatan artikel jurnal, dan bagi peserta yang belum mempunyai kegiatan penelitian dilakukan praktik pembuatan proposal penelitian.

PPM di SMKN 3 Yogyakarta yang dilaksanakan di ruang senat FT UNY pada tahun 2019 ini telah memberikan hasil berupa peningkatan keterampilan dan pengetahuan bagi guru-guru SMKN 3 Yogyakarta tentang teknik pelaksanakan PTK mulai dari persiapan, penentuan tujuan/target, pemilihan media dan metode pembelajaran yang tepat, pelaksanaan, penyusunan laporan sampai dengan bagaimana cara publikasi jurnal karya ilmiah mereka. 
Sebanyak 2 orang peserta pelatihan ini berhasil mensubmit dan mempublikasikan karya ilmiahnya di jurnal Pendidikan vokasi otomotif (JPVO).

Selanjutnya, Pada saat menjelang penutupan workshop, tim PPM di SMKN 3 Yogyakarta meminta testimoni dari peserta pelatihan mengenai manfaat yang didapatkan selama mengikuti kegiatan pelatihan. Semua peserta menyampaikan bahwa kegiatan ini sangat bermanfaat, peserta merasa senang mendapatkan pengetahuan dan keterampilan baru tentang teknik penelitian tindakan kelas. Selain itu, mereka terbuka wawasannya dan berkeinginan untuk lebih meningkatkan kemampuannya dalam melakukan penelitian tindakan kelas (PTK) dan menulis artikel/karya ilmiah.

\section{Pendampingan pasca pelatihan}

Setelah kegiatan pelatihan, peserta melakukan kegiatan lanjutan berupa penulisan proposal PTK bagi kelompok yang sebelumnya belum pernah melaksanakan PTK dan penulisan artikel ilmiah bagi kelompok yang sudah pernah melaksanakan PTK. Kegiatan pendampingan dilakukan oleh tim dosen pelaksana PPM dengan cara berkunjung ke SMKN 3 Yogyakarta sebanyak tiga kali. Pada saat kunjungan, tim dosen pelaksana melakukan pendampingan terhadap guru-guru yang sedang membuat proposal PTK ataupun menulis artikel ilmiah.

Hasil yang di dapatkan yaitu proposal PTK dan 2 artikel yang disubmit ke Jurnal Pendidikan Vokasi Otomotif (JPVO) dan sudah terbit Edisi Mei 2019. Artikel dapat dipublish ke Jurnal JPVO edisi Mei 2019 karena Jurnal tersebut masih melakukan proses review untuk artikel-artikel yang disubmit sehingga mengalami keterlambatan dan proses publikasinya. Dengan demikian, kegiatan PPM yang dilaksanakan memberikan manfaat bagi SMKN 3 Yogyakarta dan juga secara khusus untuk Jurusan Pendidikan Teknik Otomotif FT UNY dengan adanya tambahan penulis artikel dari luar institusi UNY.

\section{HASIL DAN PEMBAHASAN}

Kegiatan pelatihan PTK dengan variasi media dan metode pembelajaran untuk meningkatkan kemampuan guru SMKN 3 Yogyakarta dalam melaksanakan PTK dan menyusun artikel/karya ilmiah ini telah terlaksana dengan baik dan lancar. Kegiatan yang dilakukan pada tahun 2019 ini difokuskan yaitu untuk meningkatkan motivasi guru dalam melaksanakan penelitian dan menyusun artikel/karya ilmiah, meningkatkan kemampuan guru 
dalam memilih metode dan media pembelajaran yang tepat untuk melakukan kegiatan penelitian tindakan kelas, meningkatkan kemampuan dan ketrampilan guru dalam menyusun/menulis karya ilmiah, dan meningkatkan pengetahuan guru dalam mengakses jurnal dan forum ilmiah untuk mempublikasikan karya mereka.

Motivasi merupakan kebutuhan umum ataupun keinginan yang dapat menggerakkan seseorang untuk melakukan suatu hal/kegiatan untuk mencapai tujuan tertentu yang sudah dideklarasikan (Brophy, 2010; Brown, 2010). Motivasi seseorang dapat dipengaruhi faktor dari dalam (intrinsic motivation) ataupun faktor dari luar (extrinsic motivation) (Barto, 2013). Faktor dari dalam yang dapat mempengaruhi motivasi seseorang misalkan saja minat, bakat, ataupun keinginan untuk mengembangkan karir (Chen \& Liao, 2013). Sedangkan faktor dari luar yang termasuk dapat mempengaruhi motivasi seseorang misalkan saja hadiah ataupun keuntungan lain yang akan didapatkan ketika seseorang melakukan suatu hal tertentu (Niemiec \& Ryan, 2009). Secara umum, motivasi internal seseorang dapat memberikan dorongan yang lebih besar untuk melakukan suatu kegiatan tertentu dibandingkan dengan motivasi yang berasal dari luar (Deci, Koestner, \& Ryan, 1999). Oleh karena itu, upaya yang akan dilakukan dalam rangka meningkatkan motivasi guru untuk mengembangkan karirnya lebih cenderung bagaimana meningkatkan motivasi internal dari guru itu sendiri. Upaya yang dapat dilakukan untuk meningkatkan motivasi internal guru untuk mengembangkan karirnya yaitu dengan memberikan contoh (role model) dari tenaga pendidik yang mampu meraih karir tertinggi dalam bidangnya, memberikan pengetahuan tentang bagaimana mengembangkan karir guru, dan memberikan pengetahuan manfaat serta faktor-faktor yang mendukung ataupun menghambat guru dalam meniti karir.

Sedangkan tujuan kedua yaitu untuk meningkatkan kemampuan dan ketrampilan guru SMK dalam menyusun/menulis karya ilmiah. Maryadi dalam Harun, dkk (2001:14) memberikan pengertian karya ilmiah sebagai suatu karya yang berisi kajian tentang suatu permasalahan tertentu menggunakan kaidah-kaidah ilmiah. Karya tulis ilmiah mempunyai karakteristik merupakan tulisan dan kajian dalam suatu bidang ilmu tertentu, berlandaskan pada fakta-fakta obyektif dan/atau hasil penalaran logis, berupa hasil suatu penelitian empirik, kajian literature/pustaka, dan atau pemikiran yang disusun secara sistematis serta disajikan menggunakan kaidah bahasa yang baik, benar, dan tepat (Tatang, 2006: 1). Karya tulis/artikel ilmiah pada dasarnya merupakan penuangan suatu gagasan dan atau penelitian ilmiah/penelitian dalam bentuk tulisan menggunakan bahasa dan sistematika yang ilmiah. Berbagai jenis karya tulis ilmiah yang dapat dihasilkan oleh seorang guru misalkan saja 
makalah, hasil penelitian, modul, diktat, tulisan ilmiah populer, buku terjemahan, dan buku pelajaran. Dalam pelatihan yang dilakukan kali ini, untuk meningkatkan kemampuan dan ketrampilan guru-guru SMKN 3 Yogyakarta dalam penyusunan artikel/karya ilmiah maka diberikan pelatihan bagaimana menyusun proposal PTK, menulis laporan PTK, dan menulis/menyusun artikel ilmiah untuk dipublikasikan dalam jurnal dan prosiding.

Topik ini diambil berdasarkan hasil penelitian/survey yang dilakukan kepada peserta yaitu guru-guru SMKN 3 Yogyakarta. Berdasarkan hasil penelitian/survey sebagaimana telah dipaparkan pada hasil penelitian, diketahui bahwa, (1) terdapat 11 peserta mempunyai kegiatan penelitian yang sudah selesai dilakukan akan tetapi belum dibuat artikel jurnalnya, (2) terdapat 23 guru yang berminat untuk melakukan kegiatan penelitian tindakan kelas tahun ini, (3) Pada penawaran beberapa materi yang dibutuhkan bagi peserta, terdapat 19 peserta yang membutuhkan materi pelatihan tentang pelaksanaan PTK, 10 peserta membutuhkan materi tentang menulis laporan PTK, 11 peserta membutuhkan materi tentang pembuatan artikel jurnal, dan terdapat 1 peserta yang membutuhkan pelatihan membuat proposal R\&D.

Berdasarkan data tersebut diketahui sebanyak $44 \%$ peserta sudah mempunyai kegiatan penelitian dan belum dibuat artikel jurnalnya, sebanyak 92\% peserta berminat melakukan penelitian tindakan kelas tahun ini, sebanyak $76 \%$ peserta membutuhkan materi tentang melaksanakan PTK, sebanyak $40 \%$ peserta membutuhkan materi tentang penulisan laporan PTK, sebanyak $44 \%$ peserta membutuhkan materi tentang pembuatan artikel jurnal, dan sebanyak $4 \%$ peserta membutuhkan pelatihan membuat proposal R\&D. Kegiatan PPM ini berhasil mewadahi semua kebutuhan dari para peserta tersebut. Bagi peserta yang sudah mempunyai kegiatan penelitian namun belum dibuat artikel jurnal, telah dilakukan tutorial pembuatan artikel jurnal beserta prosedur publikasinya secara online, untuk peserta yang berkeinginan melakukan penelitian tindakan kelas tahun ini, telah dilakukan pelatihan pembuatan proposal penelitian tindakan kelas beserta pengarahan mengenai pelaksanaan dan penyusunan laporannya. Bagi peserta yang membutuhkan pelatihan pembuatan proposal R\&D sudah terwakili dengan pelaksanaan pelatihan pembuatan proposal penelitian, walaupun tidak spesifik fokus ke R\&D. Hal ini dikarenakan keterbatasan waktu dari kegiatan PPM ini, dan juga mempertimbangkan terkait hanya 1 orang yang berkeinginan melakukannya dari total keseluruhan peserta.

Kegiatan PPM di SMKN 3 Yogyakarta yang bertempat diruang senat ini dapat berjalan dengan lancar dengan peserta terdiri dari 16 guru mata pelajaran produktif dan 9 guru mata pelajaran normatif/adaptif. Pemberian materi dan tutorial yang diajarkan pada kegiatan kali 
ini sesuai dengan kebutuhan dari peserta yaitu guru-guru SMKN 3 Yogyakarta, sehingga dapat mewadahi dalam rangka upaya meningkatkan kualitas guru-guru SMKN 3 Yogyakarta dalam hal penulisan karya tulis ilmiah.

Kegiatan PPM ini berhasil meningkatkan motivasi guru untuk melakukan penelitian dan menulis karya ilmiah melalui pemberian pengetahuan mengenai pentingnya menyusun dan mempublikasikan artikel/karya ilmiah untuk meningkatkan karir guru-guru SMK, meningkatkan kemampuan guru dalam memilih media dan metode pembelajaran yang tepat untuk melakukan kegiatan PTK melalui pemberian materi tentang penyusunan proposal PTK dengan berbagai variasi metode dan media pembelajaran, meningkatkan kemampuan guru dalam menulis karya ilmiah melalui pemaparan strategi penulisan karya ilmiah prosiding dan jurnal, meningkatkan pengetahuan guru dalam mengakses jurnal dan forum ilmiah untuk mempublikasikan karya mereka melalui pemberian tutorial dan praktik langsung pembuatan proposal, jurnal, dan submit artikel jurnal secara online.

Faktor pendukung terlaksananya kegiatan PPM di SMK N 3 Yogyakarta ini adalah adanya antusiasme peserta yang tinggi untuk mengikuti kegiatan ini guna menambah kemampuan dalam penulisan karya tulis ilmiah yang digunakan salah satunya sebagai syarat naik jabatan bagi guru. Pihak manajemen SMKN 3 Yogyakarta juga sangat mendukung baik ditingkat Kepala Sekolah, Ketua Program Studi dan Guru yang secara langsung terlibat dalam kegiatan PPM. Dukungan diwujudkan dengan antusiasme mereka untuk mengikuti serangkaian acara ini. Selain itu, FT UNY juga memberikan dukungan baik berupa kesempatan, sarana prasarana, dan pendanaan yang mencukupi terhadap tim pelaksana PPM yang terdiri dari Dosen dan mahasiswa Jurusan PT. Otomotif FT UNY sehingga dapat melaksankan kegiatan PPM ini dengan baik dan lancar.

Sedangkan faktor yang menjadi penghambat yaitu kegiatan ini dilaksanakan dalam waktu libur sekolah sehingga untuk pelaksanaan penelitian tindakan kelas tidak bisa dilaksanakan, oleh karenanya kegiatan pelatihan ini masih terbatas pada praktik penulisan proposal penelitian saja, sedangkan untuk praktik pelatihan penulisan artikel dan submit jurnal dilakukan pada peserta yang sudah mempunyai kegiatan penelitian saja.

\section{SIMPULAN}

Pelaksanaan kegiatan PPM ini secara umum berjalan dengan baik dan secara khusus dapat membantu para guru di SMKN 3 Yogyakarta untuk menambah motivasi para guru untuk melakukan penelitian dan menyusun karya ilmiah, meningkatkan pengetahuan dan 
kemampuan guru untuk memilih metode dan media pembelajaran yang cocok untuk diterapkan dalam kelasnya, meningkatkan kemampuan guru dalam menyusun/menulis artikel ilmiah, dan meningkatkan pengetahuan guru dalam mengakses jurnal dan forum ilmiah untuk mempublikasikan karya mereka. Peserta pelatihan merasa puas dengan kegiatan pelatihan yang diikuti, hal ini ditunjukkan dengan pernyataan peserta yang merasa senang mendapatkan pengetahuan dan keterampilan baru tentang teknik penelitian tindakan kelas. Selain itu, mereka terbuka wawasannya dan berkeinginan untuk lebih meningkatkan kemampuannya dalam melakukan penelitian tindakan kelas dan menulis karya tulis ilmiah. Oleh karena itu, kegiatan ini disarankan untuk dilaksanakan secara berkelanjutan sehingga upaya pengembangan profesi guru dapat terus ditingkatkan.

\section{DAFTAR PUSTAKA}

Barber, M., \& Mourshed, M. (2007). How the world's best-performing schools systems come out on top. Retrieved February 13, 2018, from. http://mckinseyonsociety. com/downloads/reports/Education/Worlds_School_Systems_Final.pdf

Barto, A. G. (2013). Intrinsic motivation and reinforcement learning. In Intrinsically motivated learning in natural and artificial systems (pp. 17-47). Springer Berlin Heidelberg.

Brophy, J. E. (2013). Motivating students to learn. Routledge.

Brown, H.D. (2004). Language assessment principles and classroom practice. New York

Chen, M. H., \& Liao, J. L. (2013). Correlations among Learning Motivation, Life Stress, Learning Satisfaction, and Self-Efficacy for $\mathrm{Ph}$. D Students. The Journal of International Management Studies, 8(1), 157-162.

Deci, E. L., Koestner, R., \& Ryan, R. M. (1999). A meta-analytic review of experiments examining the effects of extrinsic rewards on intrinsic motivation. Psychological Bulletin, 125(6), 627-668.

Depdiknas Dirjen Dikdasmen Direktorat Tnaga Kependidikan. (2001). Pedoman Penyusunan Karya Tulis Ilmiah di Bidang Pendidikan dan Angka Kredit Pengembangan Profesi Guru. Jakarta:2001

Herminarto Sofyan \& Zainal Arifin. (2016). Implementasi pembelajaran saintifik pada SMK program keahlian Teknik Otomotif di Kabupaten Sleman. Laporan penelitian. 
22 Herminarto Sofyan, Wardan Suyanto, Agus Budiman, Ibnu Siswanto*, Agung Gumelar, Wahyu Arya Ruswanto

Maryadi. (2001). Pengertian dan Kriteria Karya Ilmiah. Dalam Harun, dkk. (Es). Pembudayaan Penulisan Karya Ilmiah (hlm.13-14). Surakarta: Universitas Muhammadiyah Surakarta.

Stronge, J. (2013). Effective teachers= student achievement: What the research says. Routledge.

Tatang, M,Amirin. (2006). Menulis Karya Ilmiah (Artikel). Makalah Pelatihan Penulisan Karya Ilmiah Bagi Guru-Guru se-Indonesia. Yogyakarta, 2-3 November 